\title{
OPTIMIZATION OF PRE-PRODUCTION AND PRODUCTION OPERATIONS IN THE FORESTRY INDUSTRY USING RFID TECHNOLOGY
}

\author{
Zuzana Šoltysová \\ Technical university of Kosice, Faculty of manufacturing Technologies with a seat in Presov, Department of management \\ manufacturing.. Contact: Bayerova 1,080 01 Presov, e-mail, zuzana.soltysova@tuke.sk \\ Lukáš Skarupa \\ Technical university of Kosice, Faculty of manufacturing Technologies with a seat in Presov, Department of management \\ manufacturing.. Contact: Bayerova 1,080 01 Presov, e-mail, lukas.skarupa @ student.tuke.sk
}

Keywords: RFID technology, pre-production operations, production operations, forestry industry Abstract:line The main objective of this paper is to improve logistics and design to improve the register timber in stock and timber in the sale itself to optimalization of pre-production and production operations in the forestry industry. The proposal could improve the registration using RFID technology. The proposal based on RFID technology will ensures smooth and easy flow of information. Technology will be introduced in stocks, which will result in better record keeping and transfer of timber storage and at the same time will be introduce RFID technology in the timber sale.

\section{Introduction}

RFID technology is defined as radio frequency identification, and it is a form of automatic identification and data capture. The technology utilizes the transmission of information via the electromagnetic field by radio frequency signals. It consists of four basic parts: a label reader and antenna and computer unit with software. RFID technology is a system which, uses its elements, captures and transmits data stored in the labels and displays them on a computer through the reader. It can be used in all areas related to manufacturing, logistics, transportation, registration, then in automotive and electronics industries as well as in other areas. Interest for this type of technology is increasingly growing.

The functioning process of RFID technology:

1. The label contains a chip and a helical antenna. Chip is inserted into the data. The antenna communicates with the reader.

2. The reader is also part of the antenna. The reader is a device that captures via an antenna and provides data transfer, which reader identify.

3. Computer Unit: includes software that displays data from the reader [3].

\section{Pre-production operations in the forestry industry \\ Pre-production operations include:}

1. Planning

Planning in the forest enterprises includes the following plans: NHP - National economic plan and PSL - The care program of the forest. NHP is drawn by national economic center. PSL is implemented for all forest lands, which are located in the Slovak Republic [7].

\section{Preparation of the workplaces}

During the preparation of workplaces is taken into account rational and economic character of the training in order to achieve the most effective outcome depending on the production and technical conditions in the implementation of forestry work [1].

\section{Marking trees for felling}

Trees selected for felling are marked individually with color indelible mark with a minimum diameter of five centimetres or clearly legible tion of $130 \mathrm{~cm}$ from the ground on the trunk and the root swelling. Finally, it provides a measure by meter. It measures the length and thickness of the wood [4].

\section{Production operations in the forestry industry \\ Production operations include:}

\section{Wood extraction}

Wood extraction is understood as the felling trees, its limbing and debarking. Work is dependent on the used technology in felling operations [1].

There are three types of felling:

- Restoration felling,

- Educational felling,

- Calamity felling.

The aim of regeneration felling is forest regeneration. It is often used in practice narrower term rotation felling. Educational felling focuses on the education of these stands in premature stands. Educational felling can be termed premature and term extraction, namely extraction in premature stands. Another type of felling is calamity felling. It is a random large-scale felling and imission 


\section{OPTIMIZATION OF PRE-PRODUCTION AND PRODUCTION OPERATIONS IN THE FORESTRY INDUSTRY USING RFID TECHNOLOGY \\ Zuzana Šoltysová; Lukáš Skarupa}

felling in forests dying as a result of industrial emissions. [1]. The next figure (Figure 1) describes work organisation of production operations in the forestry industry.

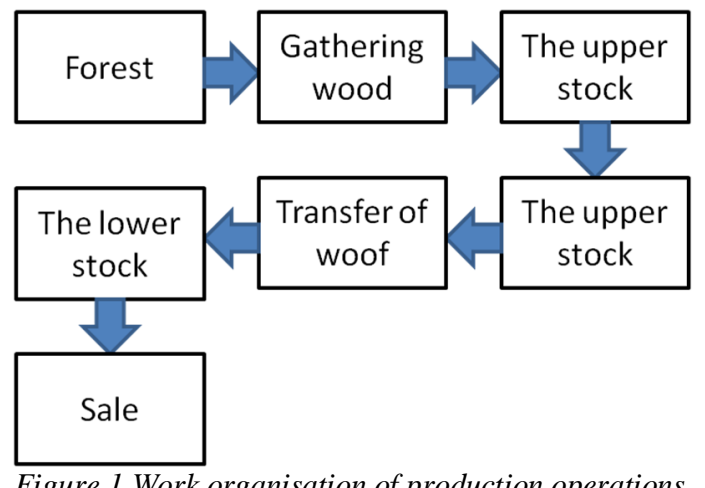

Forest - place of extraction. Gathering wood - felling wood transferred from forest to the upper stock. The upper stock - in practice it is place, where truck can get in. Transfer of wood - is linked with wood transport from the upper stock to lower stock by trucks. The lower stock - in other words, it is the manipulation - shipping stock - stock, whose function is to take over wood, registration, storage, wood handling and sale. Sale is carried out either in stock or in the form of auctions.

\section{Reforestation}

Forest regeneration is the process by which there is a replacing of the adult forest with the new forest. It is one of the basic activities of cultivation. There are three kinds of forest regeneration, namely: restoration of natural, artificial or combined.Natural regeneration is carried out under the assistance of the parent stand. The process is linked to the possible impacts of the arrived seeds on bare surface or directly under the parent stand. In order to correct natural regeneration is necessary in order to achieve favorable conditions. Artificial regeneration is carried out by means of sowing seeds or planting seedlings. Therefore, it is more expensive than natural regeneration. It raises the cost of planting and planting seedlings. Combined recovery is a combination of natural and artificial regeneration. If you can not ensure natural regeneration of the whole area, then it is necessary for filling the artificial surface to ensure recovery [2].

\section{Extracting - production technologies}

In the production process there is a change of raw product to final product. Extracting production processes change the trees in the forest to wood assortments. Extracting - production technology uses three main felling methods which are classified according to the degree of processing skidding:

- Method of product lines,

- Trunk method,

- Tree method

Product lines method performed in the stand clinker, limbing, if necessary debarking, cut up into individual tribes range. In the trunk method, the trees are cut down, debarking. When the tree method leads to the execution of woodlice in other working operations are performed at selected place (OM) [1].

\section{Felling and limbing}

First phase for wood extraction is felling (separation of above-ground tree from the ground). In terms of terrain in Slovakia, felling is carried out only by saw. Working felling operation consists of the following operations:

- Determine the direction the tree will fall,

- Modification of workplace,

- Modification of the bottom of the felling of the tree.

- Creating a notch

- The execution of the main cut,

- Rake in the direction of tree fall,

- Adaptation of the butt end and stump [1].

\section{Wood sortimentation}

Felled trees from forests are not regulated, so they are not suitable for sale. Therefore wood sortimentation must be made; it specifies the conditions of customers in terms of tree species, shape and quality.

\section{Gathering of wood}

Gathering wood is an activity related to movement of the timber stand at OM. Activity is carried out either wholly in the whole area of the timber from the forest stock, or it is divided into sections.

\section{Wood handling}

The essence is to regulate branched trunk to selections according to customer requirements. Wood manipulation according to individual tree species includes the assessment allowable size and thickness of pruning, sorting to selections, labelling and storing in heaps by product range. [3] Wood sortimentation is governed by the standard STN 480055 for coniferous trees and STN 480056 for deciduous trees [5], [6]. Wood assortments:

1st class - logs and veneer production, musical instruments and special technical needs .

2nd Class - cutouts for the production of plywood, matches , sports, technical and other special needs.

$3^{\text {rd }}$ Class- cutting logs, derricks, mining, construction, and the sleepers for various purposes without further processing

4th Class - mining logs, poles and pole stage, coniferous wood for trees.

5th Class - wood intended for the mechanical and chemical processing,

6th Class - wood for fuel [5], [6].

\section{Transfer of wood}

Wood transportation is provided in two ways:

1. The transport of wood from the forest to the upper stock. These are stocks for temporary storage wood. For a long tree, i. j. of $12.5 \mathrm{~m}$ in the upper stock, wood is shortened, so as to be able to transport over public roads,

2. Transfer of wood from upper forest stock or from lower forest stock. There is a further manipulation of the timber [7].

Last wood transport is carried out at the sale, so that the logs are transported to the customer by trailers or articulated vehicle. Hydraulic hand is used to loading the timber on the vehicle [1].

\section{Application of RFID technology in the forestry industry}

RFID technology will be used in the stocks, in the wood auctions, in the sales of wood and it improves the stock 


\section{OPTIMIZATION OF PRE-PRODUCTION AND PRODUCTION OPERATIONS IN THE FORESTRY INDUSTRY USING RFID TECHNOLOGY \\ Zuzana Šoltysová; Lukáš Skarupa}

registration. Currently, registration of timber from the forest to the stock works by pedigree timber transport and processing, where are recorded information about timber. This card contains several lines, and per line must be written of tree species, diameter, length, quality, wood volume in $\mathrm{m} 3$ etc. After the application of RFID technology should be all the necessary information entered into the tag. The stock would have the appropriate technology that would simply have registered incoming and outcoming timber.

Labels and catalogues are used at the auction of wood in company. Labels are placed on the timber and showed the number. Relevant information - of tree species, diameter and length are assigned to the numbers in the catalogue, which will receive each auction participant. The application of this technology could replace the labels by RFID tags, where the information will be saved. The worker has a manual RFID reader, would have only scans the tag and all the information as of tree species, diameter and length of the date and place of workload would be immediately viewed. It would be more transparent and easier for consumers and would not have to look for information in the catalogue.

This proposal would be also useful in the sales of wood. If customers want certain tree species of a given diameter and length and quality; the employee, attendant computer with the appropriate software, knows that in a stock is what the customer requires. It would be therefore a quick and easy download and storage timber into and from the stock, and it improves processing time. After the application of this technology would be significantly improved the flow of information storage, and an improvement in the sale of wood. It is important to choose each element appropriately to achieve efficient transfer of information.

The following picture (Figure 2) describes process of RFID technology.

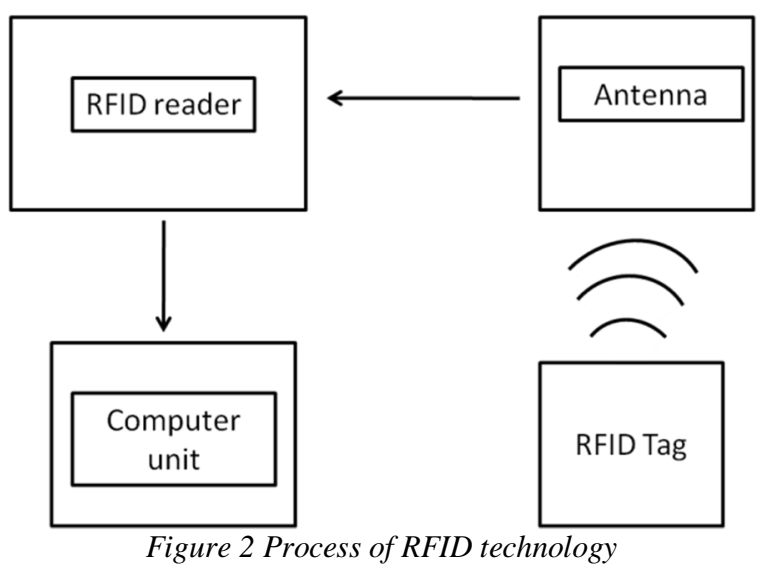

Function and location of the tag:

Tag is placed on the forehead of wood that will be further shortened and edited, it will be removed in unloading. It is advisable to select the type of the tag memory R / O (read only), it contains only the data entered during marking the timber, and it cannot be simply changed. Removed tags are rejected, as when removing tags from the front of timber, removing can causes their deformation and malfunction. The frequency range and distance range are important. The flat antenna is placed at the entrance gate, trucks with wood will pass through the entrance gate, it would be sufficient to used low-frequency tags, which have a short range, but on the other hand, this type of tag has high value and low frame rate. Therefore, it is preferable to choose tags from very high frequencies (from $300 \mathrm{MHz}$ to 3 $\mathrm{GHz}$ ) and a greater range (up to 3 meters), and to have a much lower price and better readability and you can read about 200 tags simultaneously. In terms of power tag, it is advisable to opt for passive tags, because they work without its own power. They are driven by a signal sand by antenna from reader and thus recharges the capacitor in the tag, it allows communication [3]. Subsequently, the tag is deactivated after an interruption of signal from the antenna.

\section{Function and antenna location:}

It is advisable to select the antenna with circular polarization. These antennas are distributed on two levels creating a circular effect. Constantly emitting rotating wave field ensures reliable load any tags that are in it. It is necessary to take into account the working temperature of the tags, working temperature should be in the range of $-20^{\circ} \mathrm{C}$ to $+60^{\circ} \mathrm{C}$. In view of the fact that the gate is placed far away from the building, where the system will be installed, the antenna will be placed every $5 \mathrm{~m}$.

\section{Function and location of the reader:}

The reader can reads information from the tag and transfers them to a computer unit. Antenna would be connected to the reader with cables. The reader would be located in the building.

\section{Function and location of the computer unit :}

It is needed to buy software that can reads the information. Computer unit would be connected through the card via $\mathrm{Wi}-\mathrm{Fi}$. Computer unit will be operated by trained storekeeper.

\section{The process of RFID technology application:}

1. The construction of the project (planning, graphic documentation).

2. The purchase of individual elements: software, tags, antennas, readers and computer unit.

3. Installation of purchased elements.

4. Training of employees.

Application of RFID technology in felling activity: 1. RFID tags contain a chip with memory and a helical antenna. Information on tree species, diameter, length, date of wood felling and place of wood felling will be stored in the chip.

2. Tag will have a metal casing and it will be charged with the plastic pins on each of the logs for the collection from OM to the stock. In particular, tag will be placed on the front of the log.

3. Information will be inserted into the chip and immediately sent to the foresters in stock. There would be no problem in accepting the identification in stocks or any theft of wood.

4. Wood loaded on a truck goes to the stock.

5. The antenna stored on the gateway captures the tag information after a truck entrance to the stock area.

6 . The tag is located in the electromagnetic field of antenna, and thus tags are capable of transmitting a radio signal.

7. The reader placed in the stock reads information.

8. Read information will be displayed on a computer unit.

Timber can be easily and quickly identify, and count using tags. Thanks to tag attached to the timber and device stored in the stock, it can be possible to monitor the timber from felling in the forest to the final customer. 


\section{OPTIMIZATION OF PRE-PRODUCTION AND PRODUCTION OPERATIONS IN THE FORESTRY INDUSTRY USING RFID TECHNOLOGY \\ Zuzana Šoltysová; Lukáš Skarupa}

Next figure (Figure 3) shows application of RFID technology in the stock.

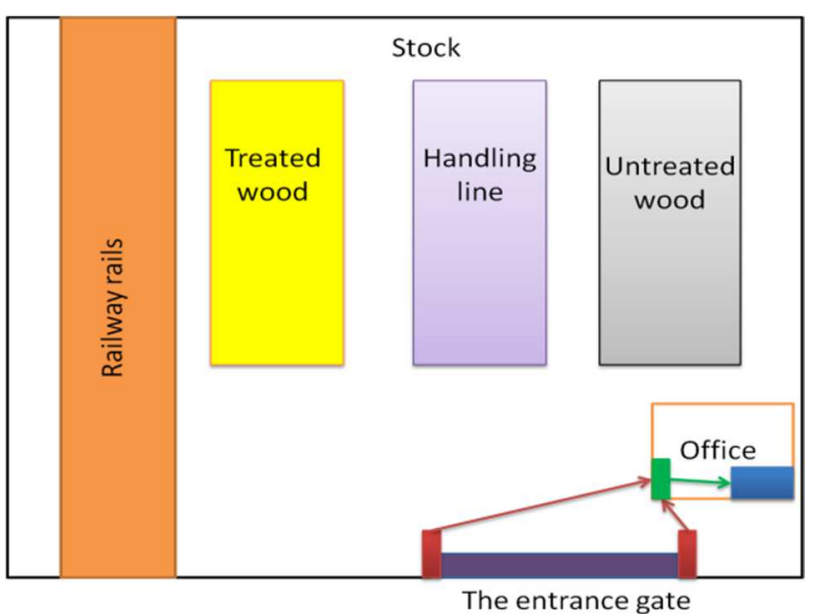

Figure 3 Application of RFID technology in the stock

The legend: Red color - antenna, it transfers information using an antenna to the office. Green color - reader, reader obtains the information and subsequently transferees them to the computer unit. Blue color - computer unit displays the information on the monitor. Yellow color - a place designed for the localisation of tags in case of wood sales.

\section{Conclusions}

Computer unit would be connected through the card via WiFi. Computer unit will be operated by trained This proposal would improves the flow of information and the sale of wood and also reduce the theft and loss of wood. Another advantage of the proposal is that the wood could not be lost. It is predicted that the losses from timber felling to its transport to the stock consist of about 20\%. After the application of the RFID technology should to reduce the loss by $10 \%$. Moreover, by recording the wood using RFID technology will not downshift the timber from a higher category to a lower category. It would also save time of workers, improving organization of work and running of the process of registration of logs in stock. The investment in this technology would be great benefit for business. This proposal would make simpler a sale of logs.

\section{References}

[1] ILAVSKÝ, Ján - KERN, Jozef: Sprístupňovanie lesov, t’ažba, doprava a manipulácia dreva. Zvolen: Ústav pre výchovu a vzdelávanie pracovníkov lesného a vodného hospodárstva, 1994. 82 s. ISBN 80-8867726-7

[2] KONôPKA, Jozef: Obnova lesa na Slovensku. Zvolen: Národné lesnícke centrum 2012. 106 s. ISBN 978-80-809-3163-6

[3] VACULÍK, Juraj, et al.: Praktikum z RFID middleware. Žilina: Žilinská univerzita v Žiline, 2012. 244 s. ISBN 978-80-554-0578-0
[4] Zákon č. 232/2006 Z.z. o vyznačovaní t’ažby dreva, označovaní vyt'aženého dreva a dokladoch o pôvode dreva.

[5] STN 48 0055:2007: Sortimentácia dreva- Ihličnaté stromy

[6] STN 48 0056:2007: Sortimentácia dreva- Listnaté stromy

[7] Internal resources of Public Enterprise Lesy Slovenskej Republiky Banská Bystrica

\section{Review process}

Single-blind peer reviewed process by two reviewers. 